\title{
Knowledge, Attitude and Perception Regarding Organ Donation among the Nursing Students
}

\author{
${ }^{1}$ Sukhpal Kaur, ${ }^{2}$ Sandhya Ghai, ${ }^{3}$ Nadiya Krishnan, ${ }^{4}$ Deepika Rana \\ ${ }^{5}$ Dimple Kathania, ${ }^{6}$ Gagandeep Kaur, ${ }^{7}$ Godawari Thakur, ${ }^{8}$ Gurinder Kaur
}

\begin{abstract}
A descriptive cross-sectional study was undertaken to assess the knowledge, attitude and perception regarding organ donation among the nursing students. The study was conducted at National Institute of Nursing Education, Postgraduate Institute of Medical Education and Research, Chandigarh. Using stratified systematic random sampling technique, 200 nursing student undergoing graduation and postgraduation courses were enrolled in the study. The tool used for data collection was a self-administered structured questionnaire consisting of three parts, i.e. information profile, assessment of knowledge, and assessment of attitude and perception regarding organ donation. For the assessment of knowledge, 17 multiple choice questions with one correct answer was used. The maximum attainable score was 18. One question had two right answers and was given a score of two. A five point Likert scale consisting of 15 questions was used for assessment of both attitude and perception of subjects regarding organ donation. Maximum attainable score was 65 . Data collected was analyzed using descriptive and inferential statistics. The results of study revealed that $74.5 \%$ of the subjects had average knowledge, $22 \%$ had poor knowledge and only $3.5 \%$ had good level of knowledge regarding organ donation. The mean knowledge score of the subjects was $10.56 \pm 2.01$ with the range of 5 to 17 . Regarding attitude and perception toward organ donation, $55.5 \%$ had neutral attitude and perception, $43.5 \%$ had positive attitude and perception and only $1 \%$ had negative attitude and perception.

It was concluded that majority of students had average knowledge about organ donation with neutral or positive attitude and perception. There is need to organize separate educational programs on organ donation for the nursing students other than their classroom teaching.
\end{abstract}

Keywords: Attitude, Knowledge, Nursing students, Organ donation, Perception.

How to cite this article: Kaur S, Ghai S, Krishnan N, Rana D, Kathania D, Kaur G, Thakur G, Kaur G. Knowledge, Attitude and Perception Regarding Organ Donation among the Nursing Students. J Postgrad Med Edu Res 2015;49(3):105-110.

Source of support: Nil

Conflict of interest: None

${ }^{1}$ Lecturer, ${ }^{2}$ Principal, ${ }^{3}$ Clinical Instructor, ${ }^{4-8}$ Intern

${ }^{1-8}$ Department of National Institute of Nursing Education Postgraduate Institute of Medical Education and Research Chandigarh, India

Corresponding Author: Sukhpal Kaur, Lecturer, Department of National Institute of Nursing Education, Postgraduate Institute of Medical Education and Research, Chandigarh India, Phone: 09888536964, e-mail: sukhpal.trehan@yahoo.in

\section{INTRODUCTION}

Organ donation is the removal of tissue from human body (living/dead) for the purpose of transplantation into another person as a treatment. ${ }^{1}$ Organs that can be donated and transplanted include kidney, heart, liver, pancreas, intestine, lungs, skin, bone marrow, cornea, etc. ${ }^{2}$ Demand of organs for transplantation continue to exceed the limited supply all over the world. This gap of demand and supply is the main obstacle to transplantation. ${ }^{3}$ There is lack of awareness and correct knowledge among public, myths and misconceptions surrounding organ donation due to religious and cultural barriers leading to hesitancy in the donation of human organ. The countries, such as China, Japan, India and Pakistan, are among those where the knowledge and practices of organ donation is quite deficient. ${ }^{4}$ In the western world, $90 \%$ of donations are from brain dead donors and only $10 \%$ are from living donors. Currently in India, about $95 \%$ of all the transplants are living donations and just $5 \%$ are from brain dead or deceased organ donors. ${ }^{5}$

Nurses have an important role to play in the process of promotion of organ donation. They can be involved in the procurement process and counseling of potential donors. In the community settings she can provide accurate and objective information concerning donation to the public. However, in the hospital she can identify the potential donor, work closely with the healthcare facility, the organ procurement organization (OPO) and/or tissue bank, provide clinical expertise, emotional support and objective and accurate information to families who are considering organ and tissue donation. She can also advocate the patients and families in the informed choice process, recognizing and respecting their cultural and religious beliefs, etc. ${ }^{6}$

In the hospital care setting, they are usually the first person who comes in contact with the dying patients. For that matter, they should learn to recognize and identify the potential organ donors as early in course of treatment as possible. They should be very vigilant while working bedside. They should have the skill of differentiating between clinical and biological death. Through careful assessment, nurses monitor for signs of brain death. So, particular attention should be paid to help nurses to develop and improve skill in this area. ${ }^{7}$ Organ and tissue 
of brain dead patient must be meticulously maintained, both hemodynamically and thermodynamically to avoid the damage and to maintain optimum function for procurement. It is the nurse who maintains hemodynamic stability so that organs of the donor remain viable by the time the other related formalities are completed. ${ }^{8}$

Randhawa suggests that nurses should be trained regarding the process of organ donation. ${ }^{9}$ A lack of knowledge regarding organ donation among medical, nursing, dentistry and health technician students has been reported by Goz et al (2006). ${ }^{10}$

The nursing students are the potential practicing nurses. They can educate the public, motivate and encourage them regarding the process of organ donation. However, it is important that they should be well equipped with the knowledge regarding organ donation. With this background, the current study was conducted to assess the knowledge, attitude and perception of nursing students regarding organ donation.

\section{METHODOLOGY}

The study was conducted at National Institute of Nursing Education (NINE), PGIMER, Chandigarh. It was a cross-sectional study of descriptive nature, conducted in the month of March 2014. The study participants were undergraduate and postgraduate students of the institute. Using stratified systematic random sampling technique, a total of 200 nursing students including 35 students from each year of BSc Nursing (4 years) program $(35 \times 4)$, 19 students from each year of BSc nursing (post-basic) $(19 \times 2)$ and 11 students from each year of MSc nursing $(11 \times 2)$ were enrolled for the study. Every 3rd students was taken from BSc Nursing (basic), every 3rd student was taken from BSc Nursing (post basic) and every 2nd student was taken from MSc Nursing.

A questionnaire consisting of 3 sections was used: Section A consists of information variables like age, sex, course being attending, religion, income of family, type of family, etc. Section B contained 17 multiple choice questions to assess the knowledge regarding organ donation among nursing students. Maximum attainable score was 18 and one question was given score of two as there were two right responses. Section $\mathrm{C}$ was a five point Likert scale consisting of 15 questions to assess the attitude and perception regarding the organ donation among the subjects. Maximum attainable score was 65 .

The institution ethical committee of Nine, PGIMER, Chandigarh, granted the ethics approval for conducting this study. All nursing students were contacted in their respective classrooms and were explained about the study. They were asked to fill-up the questionnaire within 30 minutes. Informed verbal consent was obtained from each student under study. Confidentiality of subject was maintained. The data were analyzed using mean, percentage, etc.

\section{RESULTS}

As per Table 1, around $90 \%$ of the subjects were between 17 to 24 years of age. Mean age \pm SD was $21.44 \pm 2.7$ with the range of 17 to 34 years. Majority were females. Seventy percent subjects were undergoing BSc Nursing (4 years), 19\% were undergoing BSc Nursing (post-basic) and $11 \%$ were undergoing MSc Nursing. Fifty-eight percent belonged to the Hindu religion. Fifty-two percent were from urban area and $48 \%$ were from rural area. A total of $83.5 \%$ belonged to nuclear family and $16.5 \%$ were from joint family.

Table 1: Information profile of the subjects $(n=200)$

\begin{tabular}{|c|c|}
\hline $\begin{array}{l}\text { Variables } \\
\text { Age (years) }\end{array}$ & $n(\%)$ \\
\hline $17-20$ & $87(43.5)$ \\
\hline $21-24$ & $92(46)$ \\
\hline $25-28$ & $15(7.5)$ \\
\hline 29-34 & $06(03)$ \\
\hline \multicolumn{2}{|c|}{ Mean age (years) $\pm S D=21.4 \pm 2.76$} \\
\hline \multicolumn{2}{|l|}{ Range 17 to 34 years } \\
\hline \multicolumn{2}{|l|}{ Sex } \\
\hline - Male & $5(2.5)$ \\
\hline - Female & $195(97.5)$ \\
\hline \multicolumn{2}{|l|}{ Course being attended in nine } \\
\hline - BSc Nursing (Basic) & $140(70)$ \\
\hline - BSc Nursing (Post basic) & $38(19)$ \\
\hline - MSc Nursing & $22(11)$ \\
\hline \multicolumn{2}{|l|}{ Religion } \\
\hline - Hinduism & $116(58)$ \\
\hline - Sikhism & $72(36)$ \\
\hline - Muslim & $12(6)$ \\
\hline \multicolumn{2}{|l|}{ Domiciliary background } \\
\hline - Rural & $96(48)$ \\
\hline - Urban & $104(52)$ \\
\hline \multicolumn{2}{|l|}{ Type of family } \\
\hline - Nuclear & $167(83.5)$ \\
\hline - Joint & $33(16.5)$ \\
\hline \multicolumn{2}{|l|}{ Number of family members } \\
\hline - 2-5 & $149(74.5)$ \\
\hline - $6-9$ & $47(23.5)$ \\
\hline - $10-13$ & $4(2)$ \\
\hline \multicolumn{2}{|l|}{ Monthly family income (in ₹) } \\
\hline - $<5000$ & $4(2)$ \\
\hline • 5001-20000 & $52(26)$ \\
\hline • 20001-50000 & $100(50)$ \\
\hline • > 50001 & $44(22)$ \\
\hline \multicolumn{2}{|l|}{ Per capita income (in ₹) } \\
\hline - 1000-5000 & $66(33)$ \\
\hline • 6000-10000 & $84(42)$ \\
\hline • 11000-15000 & $26(13)$ \\
\hline • 16000-20000 & $18(09)$ \\
\hline - > 20000 & $6(03)$ \\
\hline
\end{tabular}


Table 2 shows that $31 \%$ subjects had information about organ donation from television/radio, $24.5 \%$ had from curriculum, $20 \%$ had from newspaper/magazine. A total of $19.5 \%$ had heard from doctor and only $7.5 \%$ had information from seminars and workshops.

Table 3 represents the knowledge of the subjects regarding organ donation. A significant number of the subjects (99\%) were aware that family's consent is required for donation after death. A total of $96.5 \%$ knew that in case of living donation consent has to be given by donor himself and an equal number (96.5\%)

Table 2: Source of information regarding organ donation $(n=200)$

\begin{tabular}{ll}
\hline Source of information & $n^{\star}(\%)$ \\
\hline Television/radio & $62(31)$ \\
Curriculum & $49(24.5)$ \\
Newspaper/magazines & $40(20)$ \\
Doctors & $39(19.5)$ \\
Others (seminars and workshop) & $35(7.5)$ \\
\hline
\end{tabular}

*Percentage $>100$ as multiple responses were given by subjects

Table 3: Knowledge regarding organ donation among the subjects $(n=200)$

\begin{tabular}{|c|c|}
\hline Questions & $\begin{array}{l}\text { Correct } \\
\text { responses }[n(9\end{array}$ \\
\hline $\begin{array}{l}\text { For donation after death, family's consent } \\
\text { should be considered. }\end{array}$ & $198(99 \%)$ \\
\hline $\begin{array}{l}\text { Contraindications for organ donation are any } \\
\text { cancer, HIV disease, TB active or untreated, } \\
\text { donor sepsis. }\end{array}$ & $193(96.5 \%)$ \\
\hline $\begin{array}{l}\text { For living donation, consent is given by donor } \\
\text { himself/herself. }\end{array}$ & $193(96.5 \%)$ \\
\hline $\begin{array}{l}\text { The organs that can be donated by a cadaver } \\
\text { are kidney and heart, bone marrow, liver and } \\
\text { lungs, cornea and skin. }\end{array}$ & $179(89.5 \%)$ \\
\hline $\begin{array}{l}\text { The term organ donation means the removal } \\
\text { of the tissues of human body for the purpose } \\
\text { of transplantation to another person. }\end{array}$ & $175(87.5 \%)$ \\
\hline Organ donation involves risks to recipient. & $169(84.5 \%)$ \\
\hline Organs can be pledged regardless of age. & $150(75 \%)$ \\
\hline $\begin{array}{l}\text { The organs that can be donated during life } \\
\text { are kidney, pancreas and liver. }\end{array}$ & $139(69.5 \%)$ \\
\hline Organs can be donated after 18 years of age. & $102(51 \%)$ \\
\hline $\begin{array}{l}\text { Brain dead and heart beating patients are } \\
\text { eligible for cadaver organ donation. }\end{array}$ & $87(43.5 \%)$ \\
\hline $\begin{array}{l}\text { For eye donation after death, time limit is } \\
6 \text { hours. }\end{array}$ & $83(41.5 \%)$ \\
\hline $\begin{array}{l}\text { If the organs are already pledged, no consent } \\
\text { is required from the family after death of the } \\
\text { person. }\end{array}$ & $89(39.5 \%)$ \\
\hline $\begin{array}{l}\text { Awareness regarding both local and } \\
\text { international legislation with regards to } \\
\text { organ donation. }\end{array}$ & $72(36.0 \%)$ \\
\hline $\begin{array}{l}\text { No one can make decisions about organ } \\
\text { donation in case of unclaimed dead bodies. }\end{array}$ & $50(25.0 \%)$ \\
\hline $\begin{array}{l}\text { Transplantation of human organ act, } 1994 \text { is } \\
\text { the legal position on organ donation in India. }\end{array}$ & $33(16.5 \%)$ \\
\hline $\begin{array}{l}\text { Parents/guardians cannot make substitute } \\
\text { decision for mentally disabled persons in the } \\
\text { regard of organ donation. }\end{array}$ & $30(15.0 \%)$ \\
\hline
\end{tabular}

demonstrated knowledge regarding contraindications to organ donation.

As shown in Graph 1, the mean \pm SD knowledge score of the subjects was $10.56 \pm 2.1$ with the range of 5 to 17 . Majority (75\%) had average knowledge score, $22 \%$ were in the poor category and only $3 \%$ could score good score regarding organ donation.

Table 4 depicts the itemwise responses of the subjects regarding their attitude and perception toward organ donation. While $43 \%$ subjects strongly agreed, almost an equal number $(42 \%)$ agreed to consider themselves as a donor in future. Seventy percent of subjects strongly agreed that organ donation should be supported. A total of $46.5 \%$ of students agreed that there is danger of donated organs being misused, abused or misappropriated. There was strong disagreement among $45 \%$ subjects with regard to religion not supporting organ donation. Fifty-one percent disagreed that organ or tissue removal disfigures the body. Forty percent disagreed that physical and psychological disabilities of recipients matter in their decision to donate organ. Fifty-five percent strongly disagreed that religion of the recipient matter in their decision to donate organ. Fifty-seven percent agreed that they require more information and knowledge regarding organ donation.

Table 5 shows that $55.5 \%$ subjects had neutral attitude and $43.5 \%$ subjects had positive attitude regarding the organ donation. The mean score of attitude and perception was $47.8 \pm 7.203$ with the range of 24 to 65 .

Table 6 shows that majority of subjects as per all demographic variables scored in the average category of knowledge. There were more subjects with positive attitude and perception in age category of 25 to 28 years and income of 16,000 to $20,000 /$.

More than three-fourth of the subjects from all the nursing programs had average knowledge about organ donation, though the number was little more for the

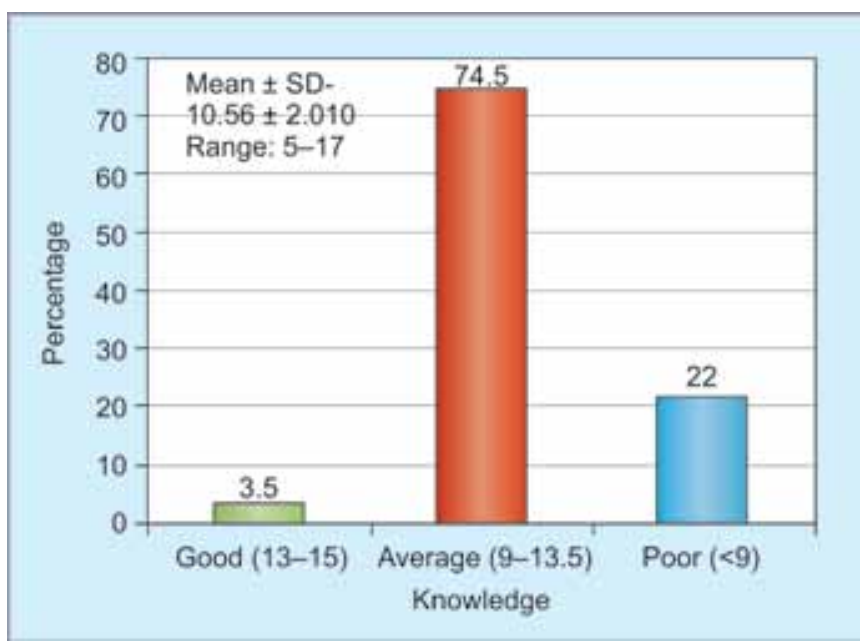

Graph 1: Knowledge score of students regarding organ donation 
Table 4: Assessment of attitude and perception regarding organ donation among nursing students $(n=200)$

\begin{tabular}{|c|c|c|c|c|c|}
\hline Item & Strongly agree $\%$ & Agree & Uncertain & Disagree & Strongly disagree \\
\hline Considering oneself as a donor in future. & $86(43)$ & $84(42)$ & $25(12.5)$ & $4(2.0)$ & $1(0.5)$ \\
\hline Organ donation should be supported. & $140(70.0)$ & $55(27.5)$ & $1(0.5)$ & $2(1.0)$ & $2(1.0)$ \\
\hline $\begin{array}{l}\text { There is a danger that donated organs could be } \\
\text { misused, abused or misappropriated }\end{array}$ & $37(18.5)$ & $93(46.5)$ & $43(21.5)$ & $23(11.5)$ & $4(2.0)$ \\
\hline My religion does not support organ donation. & $5(2.5)$ & $6(3.0)$ & $21(10.5)$ & $78(39.0)$ & $90(45)$ \\
\hline $\begin{array}{l}\text { Wealthy people and celebrities are given } \\
\text { preference for organ donation. }\end{array}$ & $20(10.0)$ & $41(20.5)$ & $39(19.5)$ & $62(31.0)$ & $38(19.0)$ \\
\hline Organ/tissue removal disfigures the body. & $5(2.5)$ & $12(6.0)$ & $29(14.5)$ & $102(51.0)$ & $52(26.0)$ \\
\hline $\begin{array}{l}\text { Your relation with the recipient matter, when you } \\
\text { are donating the organ. }\end{array}$ & $26(13.0)$ & $37(18.5)$ & $28(14.0)$ & $72(36.0)$ & $37(18.5)$ \\
\hline $\begin{array}{l}\text { Smoking status of recipient person matter in } \\
\text { your decision to donate the organ. }\end{array}$ & $9(4.5)$ & $51(25.5)$ & $44(22.0)$ & $73(36.5)$ & $23(7.0)$ \\
\hline $\begin{array}{l}\text { Drinking status (alcoholic status) of recipient } \\
\text { person matter in your decision to donate the } \\
\text { organ. }\end{array}$ & $9(4.5)$ & $55(27.5)$ & $36(18.0)$ & $76(38.0)$ & $24(12.0)$ \\
\hline $\begin{array}{l}\text { Age of recipient person matter in your decision } \\
\text { to donate the organ. }\end{array}$ & $18(9.0)$ & $54(27.0)$ & $26(13.0)$ & $71(35.5)$ & $31(15.5)$ \\
\hline $\begin{array}{l}\text { Physical disability of recipient person matter in } \\
\text { your decision to donate the organ. }\end{array}$ & $7(3.5)$ & $35(17.5)$ & $26(13.0)$ & $80(40.0)$ & $52(26.0)$ \\
\hline $\begin{array}{l}\text { Psychological disability of recipient person } \\
\text { matter in your decision to donate the organ. }\end{array}$ & $8(4.0)$ & $35(17.5)$ & $27(13.5)$ & $80(40.0)$ & $50(25.0)$ \\
\hline $\begin{array}{l}\text { Religion of recipient person matter in your } \\
\text { decision to donate the organ. }\end{array}$ & $2(1.0)$ & $10(5.0)$ & $7(3.5)$ & 71 (35.5) & $110(55.0)$ \\
\hline $\begin{array}{l}\text { Require more information and knowledge about } \\
\text { organ donation. }\end{array}$ & $66(33.0)$ & $114(57.0)$ & $4(2.0)$ & $13(6.5)$ & $3(1.5)$ \\
\hline
\end{tabular}

Table 5: Attitude and perception toward organ donation $(n=200)$

\begin{tabular}{ll}
\hline Score & {$[n(\%)]$} \\
\hline Negative (<32.5) & $2(1 \%)$ \\
Neutral (32-46.5) & $111(55.5 \%)$ \\
Positive (46.5-65) & $87(43.5 \%)$ \\
\hline
\end{tabular}

Mean \pm SD $=47.8 \pm 7.203$; Range: 24-65; Maximum attainable score $=65$

postgraduate nursing students. More students undergoing undergraduate nursing program had neutral attitude toward organ donation. However, $91 \%$ postgraduate nursing students were having positive attitude. (Table 7).

\section{DISCUSSION}

Organ transplantation could be a miracle for the person who has lost hope for life. Many people lose their lives because of nonavailability of organ. It is estimated that 1 to $4 \%$ of people who die in hospital and 10 to $15 \%$ from those who die in intensive care units are the potential donors. ${ }^{11}$ So, if the nurses working in these areas are knowledgeable enough regarding early identification of the potential donor they can influence the willingness of public to donate the organ.

This cross-sectional study was conducted among nursing students to assess their knowledge, attitude and perception regarding organ donation. The present study revealed that around two third students had average knowledge, 22\% had good knowledge and only 3.5\% students had poor knowledge regarding organ donation. Regarding attitude and perception, $55.5 \%$ had neutral attitude, $43.5 \%$ had positive attitude and only $1 \%$ students had negative attitude. The mean knowledge score was $10.56 \pm 2.01$ with the range of 5 to 17 . Actually, the current nursing curriculum includes only 1 to 2 hours of teaching regarding organ donation in the subject of medical surgical nursing. None of the subjects under study had undergone any separate training related to organ donation, but still maximum subjects had scored average score in the questions regarding knowledge. A similar study was conducted in Hong Kong among undergraduate and postgraduate nursing students which shows that subjects had average knowledge regarding organ donation and transplantation and they emphasized on the need of educational and promotional material regarding organ donation. ${ }^{12}$ Another study conducted on nurses in Hong Kong regarding knowledge and awareness regarding tissue and organ donation also found that nurses were in need of education about all aspects of brain death and organ donation including how and when to approach families to inform and ask for organ donation. ${ }^{13}$ Similarly, a survey conducted in Tehran University of Medical Sciences, Iran, on nurse's knowledge and attitude towards organ and tissue donation showed that education program can enhance nurses knowledge and commitment to the organ donation process and ultimately increase the donation rate. ${ }^{14}$

A significant number of the subjects were aware about what all organ can be donated during life and after death 
Knowledge, Attitude and Perception Regarding Organ Donation among the Nursing Students

Table 6: Knowledge, attitude and perception regarding organ donation as per identification profile of students

\begin{tabular}{|c|c|c|c|c|c|c|}
\hline \multirow{2}{*}{$\begin{array}{l}\text { Sociodemographic } \\
\text { profile }\end{array}$} & \multicolumn{3}{|c|}{ Knowledge score } & \multicolumn{3}{|c|}{ Attitude and perception scores } \\
\hline & Good n (\%) & Average $n(\%)$ & Poorn (\%) & Negative $n(\%)$ & Neutral $n(\%)$ & Positive $n(\%)$ \\
\hline \multicolumn{7}{|l|}{ Age } \\
\hline $17-20$ & $01(1.1 \%)$ & $62(71.3 \%)$ & $24(27.6 \%)$ & $0(0.0 \%)$ & $56(64.4 \%)$ & $31(35.6 \%)$ \\
\hline $21-24$ & $05(05.4 \%)$ & $74(80.4 \%)$ & $13(14.1 \%)$ & $2(2.2 \%)$ & $48(52.2 \%)$ & $42(45.7 \%)$ \\
\hline $25-28$ & $0(.0 \%)$ & $10(66.7 \%)$ & $05(33.3 \%)$ & Nil & $4(26.7 \%)$ & $11(73.3 \%)$ \\
\hline 29-34 & $01(16.7 \%)$ & $03(50 \%)$ & $02(33.3 \%)$ & $0(0.05)$ & $3(50.0 \%)$ & $3(50.0 \%)$ \\
\hline \multicolumn{7}{|c|}{ Domiciliary background } \\
\hline Rural & $17(17.7 \%)$ & $73(76.0 \%)$ & $06(06.2 \%)$ & $1(1.0 \%)$ & $58(60.4 \%)$ & $37(38.5 \%)$ \\
\hline Urban & $27(26.0 \%)$ & $76(73.1 \%)$ & $01(1.0 \%)$ & $1(1.0 \%)$ & $53(51.0 \%)$ & $50(48.1 \%)$ \\
\hline \multicolumn{7}{|l|}{ Religion } \\
\hline Hinduism & $29(25.0 \%)$ & $84(72.4 \%)$ & $03(02.6 \%)$ & $2(1.7 \%)$ & $65(56.0 \%)$ & $49(42.2 \%)$ \\
\hline Sikhism & $12(16.7 \%)$ & $56(77.8 \%)$ & $04(05.6 \%)$ & $0(0.0 \%)$ & $42(58.3 \%)$ & $30(41.7 \%)$ \\
\hline Muslim & $06(50.0 \%)$ & $06(50 \%)$ & $\mathrm{Nil}$ & Nil & $6(50.0 \%)$ & $6(50.0 \%)$ \\
\hline \multicolumn{7}{|l|}{ Per capita income } \\
\hline $0-5000$ & $15(22.7 \%)$ & $49(74.2 \%)$ & $2(3.0 \%)$ & $2(3.0 \%)$ & $42(63.6 \%)$ & $22(33.3 \%)$ \\
\hline $5,001-10,000$ & $23(27.4 \%)$ & $57(67.9 \%)$ & $4(4.8 \%)$ & $0(0.0 \%)$ & $45(53.65)$ & $39(46.4 \%)$ \\
\hline $11,001-15,000$ & $04(15.4 \%)$ & $22(84.6 \%)$ & $0(.0 \%)$ & $0(0.0 \%)$ & $16(61.5 \%)$ & $10(38.5 \%)$ \\
\hline $16,000-20,000$ & $02(11.1 \%)$ & $15(83.3 \%)$ & $1(5.6 \%)$ & $0(0.0 \%)$ & $5(27.8 \%)$ & $13(72.2 \%)$ \\
\hline$>20,000$ & $\mathrm{Nil}$ & $06(100.0 \%)$ & $\mathrm{Nil}$ & $0(0.0 \%)$ & $3(50.0 \%)$ & $3(50.0 \%)$ \\
\hline
\end{tabular}

Table 7: Knowledge, attitude and perception regarding organ donation as per the nursing program being pursued

\begin{tabular}{llllllll}
\hline & \multicolumn{3}{c}{ Knowledge } & & \multicolumn{3}{c}{ Attitude and perception } \\
\cline { 2 - 4 } Program being pursued & Good & Average & Poor & & Negative & Neutral & Positive \\
\hline BSc Nursing (4 years) & $33(23.6 \%)$ & $102(72.9 \%)$ & $05(3.6 \%)$ & & Nil & $86(61.4 \%)$ & $54(38.6 \%)$ \\
BSc Nursing (post basic) & $07(18.4 \%)$ & $29(76.3 \%)$ & $2(5.3 \%)$ & & $02(5.3 \%)$ & $23(60.5 \%)$ & $13(34.2 \%)$ \\
MSc Nursing & $04(18.2 \%)$ & $18(81.8 \%)$ & Nil & & Nil & $2(9.1 \%)$ & $20(90.9 \%)$ \\
\hline
\end{tabular}

and that family's consent is required for donation after death and in case of living donation, consent has to be given by donor himself/herself. Subjects also have demonstrated good knowledge regarding contraindications to organ donation. Subjects showed lack of knowledge in certain areas, such as legal position of organ donation in India and consent procedures about organ donation after death. More than half of subjects were unaware about the concept of brain death in case of the cadaveric organ donation and only one fourth of subjects were aware about the fact that no one can make decision of organ donation in case of unclaimed dead body and only half of subjects were aware about the legal age of organ donation in India.

Majority of the students undergoing postgraduation had positive attitude and perception toward organ donation. Probably, they have read more about the subject. So, education can definitely have as impact on this cause. McGlade D et al have reported that changes in attitude postintervention were observed in relation to participants' willingness to accept an informed system of consent and with regard to participants' actual discussion behavior. ${ }^{15}$ The attitude and perception can be the result of many reasons, religious being one of the main. Many religions, though favorable toward the ideology of organ donation, are hesitant about the criteria involved in this procedure. However, in the current study, almost comparable number of subjects belonging to all the three religions showed neutral or positive attitude toward organ donation. But, in a survey conducted on Muslims about their attitude toward donation $68.5 \%$ agreed to the idea of donation but only $39.3 \%$ believed it was compatible with Islam. ${ }^{16}$

The knowledge of nurses about different aspects of donation process is essential because they can improve public awareness about organ donation and hence contributing to the improved donation process. We recommend that special educational program should be organized for the nursing students to improve their knowledge regarding organ donation. Because, it has been reported that formal training about organ donation can successfully influence student nurses' attitudes, encourage communication and registration behaviors and help improve knowledge about donor eligibility and brain death. ${ }^{17,18}$

\section{CONCLUSION}

Majority of the students had average knowledge regarding organ donation. Around half each had neutral and positive attitude regarding organ donation. 


\section{REFERENCES}

1. Saleem T, Ishaque S, Habib N, Hussain SS, Jawed A, Khan AA, et al. Knowledge, attitude and practices survey on organ donation among a selected adult population of Pakistan. BMC Medical Ethics. 2009;10(5). Available at: http:/ /www. biomedcentral. com/1472-6939/10/5.

2. Organ transplantation. Available at: https://en.wikipedia. org/wiki/organ transplantation. Accessed on 15 June 2014.

3. Khan N, Masood Z, Tufial N, Shaukat H, Asharaf K, Ehsan S, et al. Knowledge and attitude of people towards organ donation. JUMDC 2011;2(2):15-21.

4. Ali NF, Quershi A, Jilani BN, Zehra N. Knowledge and ethical perception regarding organ donation among medical students. Bio Med Central Ethics 2013;38(14):14-38.

5. Shroff S, Navin S, Abraham G, Rajan P, Suresh S, Rao S, et al. Cadaver organ donation and transplantation-an Indian Perspective. Transplant Proc 2003;35(1):15-17.

6. Available at: http://www.nysna.org/practice/positions/ positions10_04 htm. Role of the Registered Professional Nurse in Organ and Tissue Donation. Accessed on: 15 June 2013.

7. Kaur S, Singh M. Clinical neurosciences and critical care nursing. 1st edition. Jaypee Brothers Medical Publishers Private Limited. 2014. p. 375.

8. Piffer K. Brain death and organ procurement. AJN 2007;107(3): 58-67.

9. Randhawa G. Specialist nurse training programme: dealing with asking for organ donation. J Advanced Nursing 1998; 28(4):405-408.

10. Goz F, Fugen, Goz M, Erkan M. Knowledge and attitude of medical, nursing, dentistry and health technician students towards organ donation: a pilot study. J Clin Nursing 2006; 15(5):1371-1375.
11. Cinque VM, Bianchi ERF, Araujo EAC de. O tempo envolvido para a constataacao da morte encefalica. J Nurs UFPE online [Internet]. 2009 July/Sept [cited 2012 jan 15];3(3):66-72. Available at: http://www.ufpe.br/revistaenfermagem/index. $\mathrm{php} / \mathrm{revista} /$ issue/view/8.

12. Tam WWS, Suen LKP, Chan HYL. Knowledge, attitude and commitment towards organ donation among nursing students. Transplantation Proceedings 2012 June;44(5): 1196-1200.

13. Ozdag N. The nurses knowledge, awareness and acceptance of tissue organ donation. DTNA ERCA J 2001;27(4): 201-206.

14. Aghayan HR, Arjmand B, Emami-Razavi SH, Jafarian A, Shabanzadeh AR, Jalali F, et al. Organ donation workshop: a survey on nurses knowledge and attitude toward organ and tissue donation in Iran. Int J Artificial Organs 2009;32(10): 739-744.

15. McGlade D, Pierscionek B. Can education alter attitudes, behaviour and knowledge about organ donation? A pretest-post-test study. BMJ Open 2013;3:e003961 DOI:10.1136/ bmjopen-2013-003961.

16. Sharif A, Jawad H, Nightingale P, Hodson J, Lipkin G, Cockwell $\mathrm{P}$, et al. A quantitative survey of Western Muslim attitudes to solid organ donation. Transplantation 2011;92(10): 1108-1114.

17. López-Montesinos MJ, Manzanera Saura JT, Mikla M, et al. Organ donation and transplantation training for future professional nurses as a health and social awareness policy. Transplant Proc 2010;42:239-242.

18. Abbasi Dolatabadi Z, Farahani B, Fesharaki M. Effect of education about brain death and organ donation on attitude and knowledge of nursing students. Iran J Crit Care Nurs 2010;3:109-112. 